小脳疾患, 仮性球麻痺, 筋萎縮性側索硬化症 による麻痺性構音障害の話しことばの特徴

\author{
藤 林 真理子* 福 迫 陽 子** 物 井寿 子** \\ 小 林 範 子*** 辰 巳 格*** 廣 瀬 肇 ${ }^{* * * * *}$
}

\title{
Characteristics of Dysarthric Speech due to Cerebellar disorders, Pseudobulbar Palsy and Amyotrophic Lateral Sclerosis
}

\author{
Mariko Fujibayashi, Yoko Fukusako, Hisako Monoi, \\ Noriko Kobayashi, Itaru Tatsumi and Hazime Hirose
}

With the objective of analyzing and describing the characteristic patterns of deviant speech of patients in three discrete neurologic groups(cerebellar degeneration, pseudobulbar palsy and amyotrophic lateral sclerosis), speech samples of each patient consisting of sentences and repetitions of syllables were used for rating on each of 39 predetermined dimensions of speech and voice. Analysis based on the means of the ratings of the eight judges on each patient on each dimension yields results leading to the following conclusions: (1) Ratings for sentence samples were higher than those for repetitions of syllables. (2) Some of the dimensions highly deviant in each group were common to all three groups, such as imprecision of consonants and slow rate, while others were characteristic of each group. (3) Speech and voice of the group with cerebellar disorders were found to be characterized by irregular articulatory and phonatory break down, whereas those of the other two groups were found to be lacking in resonatory-articulatory and phonatory competence, the two groups varying in degree in some of the dimensions. (4) The above characteristics seem to mirror the general abnormalities of motor functions in each group. (5) Our findings are comparable to those of Darley et al. and Hirose with some exceptions one of which is considered to be due to the difference of language.

\section{1. はじめに}

麻痺性構音障害 (dysarthria) とは, 発声発語を行う 運動遂行の過程に関与する筋・神経系の病変（血管障害 性, 炎症性, 萎縮変性性, 腫瘍性, 中毒性, その他) に よって起こる, 話しことば（speech）の障害をいう. 発

\footnotetext{
* 虎の門病院

** 東京都養育院附属病院

$* * *$ 北里大学病院

**** 東京都老人総合研究所

****** 東京大学医学部音声言語研究施設
}

声発語の遂行過程には, 大脸の運動皮質から効果器であ る筋肉に至る様々な段階があり，この系のどの段階に病 変が存在するかにより症状が異なる．したがって，臨床 症状をもとにして病变の存在する段階をある程度鑑別す ることも可能であると考えられる.

麻疾性構音障害を来す神経疾患の鑑別は, 一般的な神 経学的検査法や, 筋電図, 筋生検などの臨床検査に基つ” いて行われている.一方，話しことばの上にもそれぞれ 神経疾患による特徵が認められることは従来から知られ ており，その全体的印象から，「ろれつが回らない」(仮 性球麻痷など),「断綴性, bradylalia, slurred speech」 
表 1 Darley らによる麻㽻性構音障害の分類

\begin{tabular}{|c|c|}
\hline 名 & 障 害 部 位 \\
\hline 1. 弛緩性麻痷性構音障害 : 球麻瘒など & 下位運動ニューロン \\
\hline 2. 痙性麻疩性構音障害 : 仮性球麻瘏 & 上位運動ニューロン（両側性） \\
\hline 3. 失調性麻疩性構音障害 : 小脳疾患 & 小脳または小脳路 \\
\hline $\begin{array}{l}\text { 4. 運動減少型麻瘒性構音障害 } \\
\text { パーキンソン氏病 }\end{array}$ & 錐体外路 \\
\hline 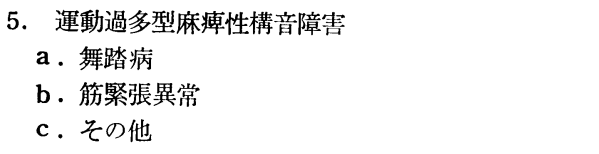 & $\begin{array}{l}\text { 錐体外路 } \\
\text { 速い運動過多型 } \\
\text { 遅い運動過多型 }\end{array}$ \\
\hline 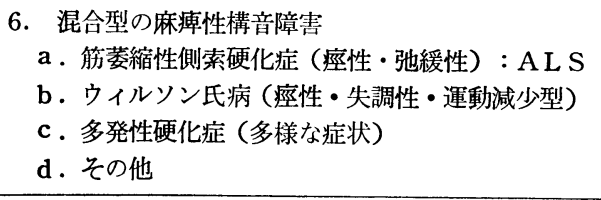 & 多系統 \\
\hline
\end{tabular}

(小脳疾患) などが挙げられている.しかしながら，こ れらの用語は, 研究者によって必ずしも一致していると はいえずまた，これらの用語は各神経疾患における話 しことばの詳細な特徵を記述するには不十分である。し たがって，このようなとらえ方によって話しことばの異 常が何に起因するかを解明することは，きわめて困難で あるといわざるをえない。このため Darleyら 麻㽻性構音障害を呈する種々の中枢神経疾患（表 $1^{3)}$ ) に関し，それぞれの疾患に属する症例の話しことばの特 徵をより分析的にとらえるため, 聴覚印象に基づく分析 を試みた。彼らは, 症例 1 人につき, ほほ330秒の発話 (自発語) を録音し，これを 3 人の判定者に聞かせ， 38 の評価項目について 7 段階評価を行った。 その結果, 各 疾患群の示す話しことばの特徵が抽出され, さらにこれ らの特徵と神経学的所見との間に密接な関連があること が報告された。一方, 日本語に関しては, 広瀬 ${ }^{4}$ が $\mathrm{Da}$ rley らの評価項目を日本語に適するよう改訂して25項 目を設定し, 比較的長時間の発話サンプルを用いて, 少 数例についての結果だが， 6 疾患群の特徴を抽出してい

\section{る。}

われわれは, 広瀬の用いた評価項目をもとに, さらに 細かく特徵を抽出できるように評価項目を変更し, 小脳 疾患 ${ }^{5)}$, 仮性球麻疩および筋萎縮性侧索硬化症（以下, A L S と略す）の 3 疾患群のより多数例について話しこ とばを評価したので，その結果について述べる。

なお，本論を続けるにあたり，今後の理解をより容易 にするために, われわれが対象とした疾患について神経 学的特徵を簡単に述べておくことにする.

小脳疾患 : 小脳障害の原因には脳血管障害, 変 性 疾 患, 腫瘍, 炎症, 中毒などがあるが, われわれが対象と
したのはいわゆる春髄小脳変性症である。これには, 初 発年齡, 遺伝性の有無, 障害部位の広がりなどを異にす るマリー型,フリードライヒ型,オリーブ核脳橋小脳萎縮 症 (Olivo-ponto-cerebellar atrophy, OPCA), 晚発性皮 質性小脳萎縮症 (Late cortical cerebellar atrophy, LC CA 型）などのタイプがあるが，いずれも進行性で，主 な症状は失調, 眼振および筋緊張低下である.

仮性球麻瘏：運動皮臫に始まり，皮質下，脳幹を通り 延䯣神経核に至る上位運動ニューロンに病変が生じた場 合に起こるのが㾏性麻㽻である。そのうち，仮性球麻痺 は両側性の病変によるものであり, 脳血管障害, 外傷な どの後遺症として起こることが多い. 症状は球麻㽻に似 ているが, 運動麻瘏, 運動不全のほか, 筋緊張の異常, 反射兄進などの症状も混在する.

筋萎縮性側索硬化症：上位および下位運動ニューロン に病変が広がる進行性疾患であるため, 球麻痺と仮性球 麻㽻の症状が混在するが，時期により前景に出る症状は 異なる。ほとんどの例は孤発例で, 発症年 龄は40代 後 半, 生存期間は発症後 $3 ， 4$ 年ということが多い. 主な 症状は, 筋萎縮, 筋力低下, 筋線維束攣縮, 反射異常打 よび筋緊張異常などである。

\section{2. 方 法}

1）対象は, 虎の門病院,東京大学医学部附属病院,東 京都養育院附属病院, 北里大学病院および川口医師会病 院において，専門医による神経学的検査の結果，確定診 断を受けた小脳疾患例20名（全例とも脊䯣小脳变性症. 男13名, 女 7 名, 年齡24 60歳), 仮性球麻疩例20名(男 17名, 女 3 名, 年齢21〜72歳）およびA L S 例30名（男 17名, 女13名, 年齢16～73歳）である. 
表 2 麻痺性構音障害 評価項目

\begin{tabular}{|c|c|c|c|}
\hline & 項 & & 項 \\
\hline 声の高さ & $\begin{aligned} 1 & \text { 高すぎる } \\
2 & \text { 低すぎる } \\
3 & \text { 高さが変動する } \\
4 & \text { 高さの変動が急に起こる (break) } \\
* 5 & \text { 一様である (monopitch) }\end{aligned}$ & \multirow[t]{2}{*}{ 話 し 方 } & $\begin{array}{ll}22 & \text { short rushes } \\
23 & \text { 音節の長さの不規則なくずれ } \\
24 & \text { 音がバラバラにとぎれる } \\
25 & \text { 一つの音が引き伸ばされる } \\
26 & \text { たびたび息つぎがある }\end{array}$ \\
\hline \multirow{2}{*}{ 声質 } & \multirow{2}{*}{$\begin{aligned} 6 & \text { 粗䊐性 } \\
7 & \text { 気息性 } \\
8 & \text { 無力性 } \\
9 & \text { しぼりだすような努力性 } \\
10 & \text { 声の質が変化する }\end{aligned}$} & & $\begin{array}{ll}* 28 & \text { 話し方が単調 } \\
* 29 & \text { (㫓のような) 繰り返しが起こる }\end{array}$ \\
\hline & & & \multirow{2}{*}{$\begin{array}{ll}30 & \text { 開鼻性 } \\
31 & \text { 閉鼻性 } \\
32 & \text { 鼻からの息もれ (emission) } \\
33 & \text { 母音のくずれ } \\
34 & \text { 子音の置きかえ } \\
35 & \text { 子音の省略 } \\
36 & \text { 子音のくずれ (歯切悪い, 不鮮明, 歪み) } \\
37 & \text { 構音のくずれが non-systematic または } \\
& \text { 間欠的に起こる }\end{array}$} \\
\hline 声の大きさ & $\begin{aligned} & 11 \text { 大きすぎる } \\
& 12 \text { 弱すぎる } \\
& 13 \text { 大きさが変動する } \\
& 14 \text { 変動が急に起こる (爆発性) } \\
& * 15 \text { 一様である (monoloudness) } \\
& 16 \text { だんだんに弱くなる } \\
&\end{aligned}$ & 共鳴 構 音 & \\
\hline \multirow{2}{*}{ 話 し 方 } & \multirow{2}{*}{$\begin{array}{ll}17 & \text { 速すぎる } \\
18 & \text { 遅すぎる } \\
19 & \text { 速くなったり遅くなったり } \\
20 & \text { だんだんに速くなってしまう } \\
21 & \text { だんだんに遅くなってしまう }\end{array}$} & 全体評価 & \begin{tabular}{|ll}
$* 38$ & 全体としての明瞭度 \\
39 & 異常の程度 \\
\end{tabular} \\
\hline & & \multicolumn{2}{|c|}{ * は音節の繰り返しでは行っていない } \\
\hline
\end{tabular}

2）発話サンプル：各症例について文および音節の繰 り返しの 2 種のサンプルを作成した. 文のサンプルは, 自由会話, 文章朗読, 数個の短文の音読または復唱を 3 分〜 4 分半に編集したものであり, 音節の繰り返しは, パ，タ，カおよびパタカのおのおのをできるだけ速く繰 り返させたもの約 20 秒である.文のサンプルを比較的長 時間としたのは，Darley らのように30秒では，十分に 評価しえないと考えたためである。

3) 評価方法

(1) 評定者：発話サンプルの評価にあたったのは，耳 鼻咽喉科医師 1 名, 言語治療士 7 名の計 8 名である.こ れらの評価者はすべて麻痺性構音障害に接する機会が多 く，十分な臨床経験を有している。

(2) 評価項目 : Darley ら，および広瀬の用いた項目 をもとに検討を行い，最終的には39の項目を設定した (表 2 ). このうち, 項目 1 から項目37までは, 話しこ とばの要素を分析的に評価するもので，声（高さ，声 質, 大きさ), 話し方, 共鳴・構音の 3 つに大別される. 項目38および39は, 全体的な発語明膫度と異常度を評価 するために設けた。各評価項目とも文, 音節の繰り返し を別々に評価したが, 後者では課題の性質上不適当と思 われる項目はあらかじめ省いた。たとえば，項目 5 （声 の高さが一様である)，15（声の大きさが一様である） および28（話し方が単調）は，本来一様に発話すること
を目的としているので評価を行わなかった。このほか, 項目29（吃のような繰り返しが起こる）, 38（全体とし ての明膫度）も除外した.したがって, 各症例あたり, 文では39項目, 音節の繰り返しでは34項目の合計73項目 について評価を行った。

評価に先立ち, 評価者による各項目の解釈の不一致を 避ける目的で，次のような手続きを行った。すなわち， 2 名の症例の発話サンプルについて, あらかじめ, 各項 目の解釈について話し合った後, 各人が評価し, その結 果をもとに評価項目や採点の解釈の統一を図った.

(3) 評価点: 評俩点は, 発語明瞭度の項目を除き, 文, 音節の繰り返しとも, 異常の最も著しい場合を 3 点 とし, 異常が涩められない場合を 0 点とする 4 段階評価 を行った. 発語明瞭度の項目については, 言語病理学で 一般に用いられている 5 段階評洒に従った。

$1 \cdots \cdots \cdots$ よいかかる.

$2 \cdots \cdots \cdots$ 時々わからない語がある.

3 ……聞き手が話題を知っていて聞いていれば どうやらわかる。

4 ……時々わかる語がある.

$5 \cdots \cdots \cdots$ 全く了解不能.

評価は各自別個に行い, 各症例の発話サンプルについ てすべての項目を評価し終わるまで十分に繰り返し聴取 させることとし，評価点は各項目ごとに所定の用紙に記 
入させた.

(4) 再現性の検討：評価の再現性については，5名の 症例（仮性球麻疩 2 名, A L S 3 名) を選び， 1 回目の 評価の 2 力月後に再評価して, 各評価者の 2 回の評価点 の相関係数を求めたところ, 仮性球麻瘢では0.64から 0.94までで平均 0.85 , A L S では 0.69 から 0.91 までで平 均0.81であり，比較的再現性の高いことが認められた。

\section{3. 結果と考察}

図 1 は, A L S 群の症例に対する評価者全員の評価点 の平均值 (MEAN SCALE VALUE. 以下, MSV と略 す）を文と音節の繰り返しについて比較したものであ る.㘡の綎軸は文におけるM S Vを示し，横軸は音節の 繰り返しテストでのMSVを示している．また，図中の 数字は評価項目の番号である. 図に見られるように，文 と音節の繰り返しにおける各項目の得点は非常に高い正 の相関 $(r=0.93)$ を示している（これは他の 2 疾患でも 同様であり，小脳疾患では 0.88 , 仮性球麻疾では0.93て あった)．文と音節の繰り返しを比較すると文の方が得 点が高くなっているが，一方，項目18（遅すぎる），21 （たんだんに遅くなってしまう）などでは，逆に音節の 繰り返しの方が得点が高く, したがって, 後者では発話 速度に関する特徵をとらえやすいものと考えられる．小 脳疾患招よび仮性球麻痺に打いても，同様の関係が見ら
れた。

以下の検討に括いては，大多数の評価項目で各疾患群 の特徵がはっきり出た，文についての評価結果を中心に 述べることにする。

表 3 は，文について高得点項目(ここではM S Vが 0.5 を越える項目)，すなわち異常度の高い項目を各疾患群 ごとに示したものである。脸疾患では，「子音のくず れ」,「構音のくずれが non-systematic または間欠的に 起こる」，「子音の省略」などの構音の不正確さを表す特 徵や，「音がバラバラにとぎれる」，「一つの音が引き伸 ばされる」および「遅すぎる」などの速さの低下を示す 特徵が高得点項目となっている。このうち，「構音のく ずれが non-systematic または間欠的に起こる」を除く 5 項目は，次に述べる仮性球麻痺求よびA L S そ执いて もほぼ共通に見られる。これに対して，他の群に共通で ない項目，言い換えれば，小脳疾患を特徴づける項目 は，「構音のくずれが non-systematic または間欠的に起 こる」のほか，「音節の長さの不規則なくずれ」，「速く なったり避くなったり」および「声の高さ，大きさが変 動する」などの，発声㐨よび構音の変動性ならびに不規 則性，話し方の不規則性を表す項目である。これらの項 目は，上記の項目と合わせて，いわゆる slurred and scanning speech, 爆発性, bradylalia などといわれる 小脳疾患の話しことばの特徵を分析的に示すものである

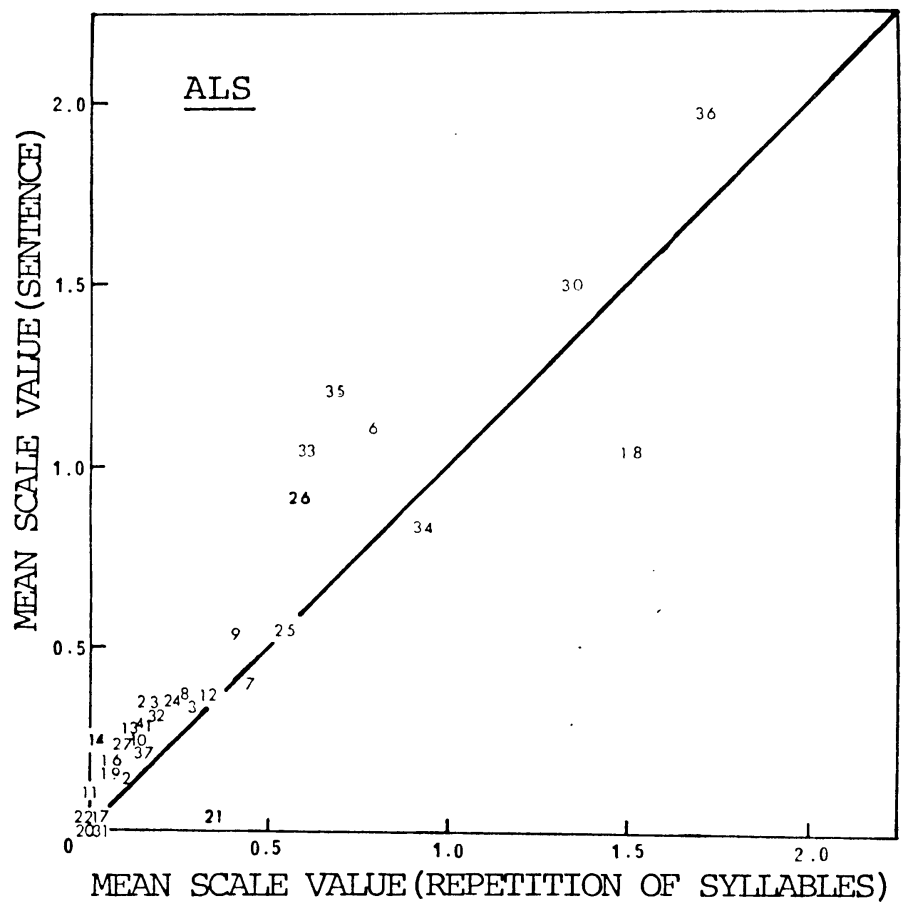

图 1 A L S の文と音節の繰り返しの得点の比較 
表 3 各疾患群の高得点項目

\begin{tabular}{|c|c|c|}
\hline (a) 小脳疾患 & （b）仮性球麻痺 & (c) ALS \\
\hline 36 子音のくずれ & 36 子音のくずれ & 36 子音のくずれ \\
\hline 37 構音のくずれが間久的に起こる & 35 子音の省略 & 30 開鼻性 \\
\hline 23 音節の長さの不規則なくずれ & 28 話し方が単調 & 35 子音の省略 \\
\hline 35 子音の省略 & 33 母音のくずれ & 6 粗精性 \\
\hline 24 音がバラバラにとぎれる & 6 粗粘性 & 18 遅すぎる \\
\hline 13 声の大きさが変動する & 18 遅すぎる & 33 母音のくずれ \\
\hline 19 速くなったり遅くなったり & 5 声の高さが一様 & 28 話し方が単調 \\
\hline 3 声の高さが変動する & 30 開鼻性 & 34 子音の置きかえ \\
\hline 18 遅すぎる & 26 たびたび息つぎがある & 26 たびたび息つぎがある \\
\hline \multirow[t]{7}{*}{25 一つの音が引き伸ばされる } & 15 声の大きさが一様 & 5 声の高さが一様 \\
\hline & 7 気息性 & 15 声の大きさが一様 \\
\hline & 25 一つの音の引き伸し & 25 一つの音の引き伸し \\
\hline & 34 子音の置きかえ & 9 努力性 \\
\hline & 9 努力性 & \\
\hline & 12 弱すぎる & \\
\hline & 24 音がバラバラ & \\
\hline
\end{tabular}

と同時に，小脳疾患に認められる一般的な運動障害の特 徵を反映したものと考えられる。

仮性球麻疩では, 高得点項目の数が 3 群中最も多く, また，その特徵も多岐にわたっている，まず，構音に関 しては，「母音，子音のくずれ」，「子音の置きか光」, 「子音の省略」,「開鼻性」なぞの項目の得点が高く, 構 音の正確さに欠けることを示している。これらの異常 は, 構音器官の筋力低下により, 運動の範囲や力が低下 しているために生じたものと推測される。話し方に関し ては, 構音器官の筋力低下, 過緊張拈よび反射方進によ ると思われる「遅すぎる」,「一つの音が引き伸ばされ る」,「音がバラバラにとぎれる」などの項目が見られ る.そして, 発声に関しては, 過度の声門閉鎖 (内転筋 群の過緊張によると思われる）による「しぼり出すよう な努力性」や「粗粘性」, あるいは声带運動不全に関係す ると考兄られる「気息性」,「弱すぎる」などの声質の異 常を表す項目や，「声の高さ，大きさが一様である」な ど, 主として声帯の緊張調節の障害を示す項目，「たび たび息つぎがある」,「音がバラバラにとぎれる」などの 呼気調節機能, あるいは呼吸機能の障害を示す項目など が見られる。

仮性球麻痺の話しことばの特徵は, このように多様で あるが, その主な要因として, 発声発語器官の運動の範 囲や強さの低下と運動の遅さを挙げることができ，一般 に，「話し方がはっきりしない」「「ろれつが回らない」 といわれる仮性球麻㿁の話しことばの特徵が分析的に示 されたものといえよう。ささらに, 発声発語器官におけ る, 運動の範囲や強さの低下, さらに運動の速さの障害 を生じる要因の一つは，「努力性」および「開鼻性」に
代表される，異なる筋の過緊張と筋力低下の併存である と思われる。このことは，四肢に見られる痓性麻痺（た とえば，上肢では，通常，屈筋に過緊張が現れる）が， 発声発語器官にも起きたものと解积される。

A L S 群の高得点項目は, すべて仮性球麻盘の高得点 項目にも含まれており，このことは，両群の話しことば の特徽がよく似ていることを示している.図 2 は, 両群 のMS Vを全項目にわたって比較したもので, 綖軸はA L S 群, 横軸は仮性球麻痺群の M S V, 図中の数字は評 価項目の番号を示している. 図から明らかなように, 両 群のM S Vは, きわめて高い正の相関 $(r=0.93)$ を示す が，図中の回帰直線からのずれの大きい項目を強いて挙 げるとすれば, 項目30 (開鼻性) であり, 大多数の項目 とは逆に, A L S 群の得点が高くなっている.これは, 仮性球麻瘏群に見られた口盍帆挙上筋の筋力低下に, 筋 菱縮が加わったことを示するのであろう．

ついでながら，AＬＳ群および仮性球麻痺群と小脳疾 患群のMSVの相関係数は，それぞれ，0.39，0.33と低 く, 小脳疾患群の話しことばの特徵が他の 2 群とは相当 異なり，症候論的に違った要素を有することを示してい る.

最後に，今回の結果と従来の報告とを比較してみた い.まず, Darleyら ${ }^{123)}$ の結果と比較してみる. Darley らの評価項目は，今回のそれとは必ずしも一致せず，評 価方法にも若干の違いがある。さらに， Darley らは高 得点項目のみを発表しており, 他の項目については知る ことができない。したがって，ここでは， Darley らの 高得点項目およびこれにほぼ対応するわれわれの評価項 目について倹討することにしょう。図3は，各群につい 


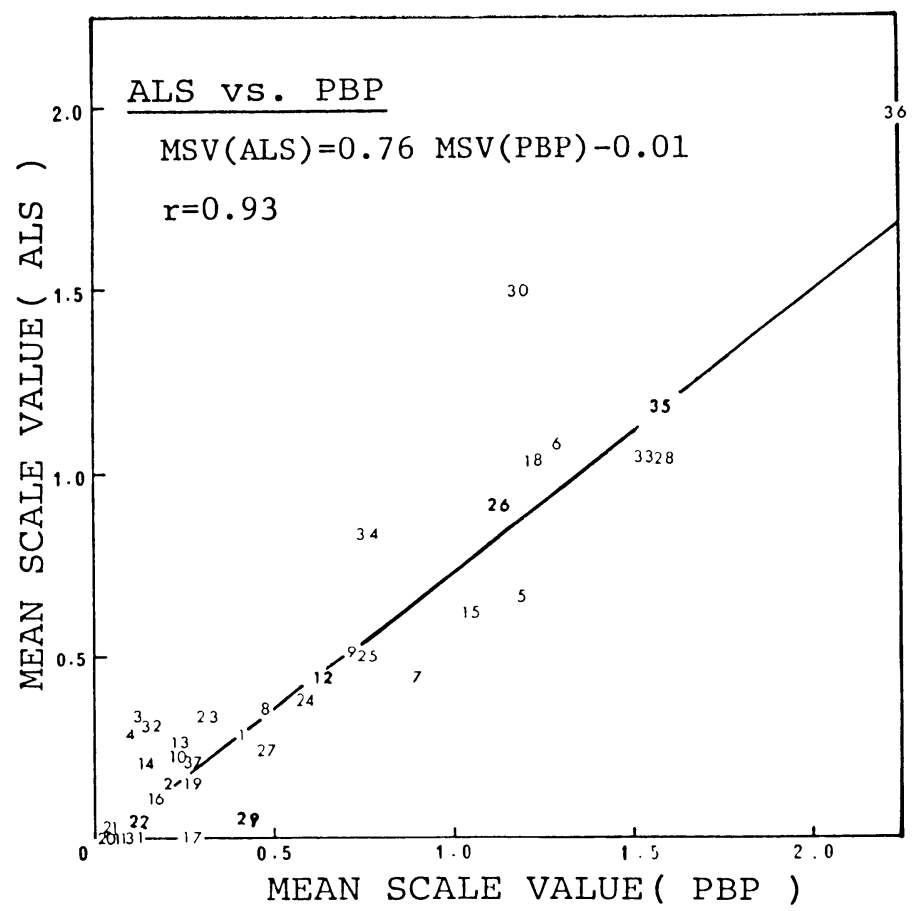

図 2 A L S と仮性球麻疩の得点比較

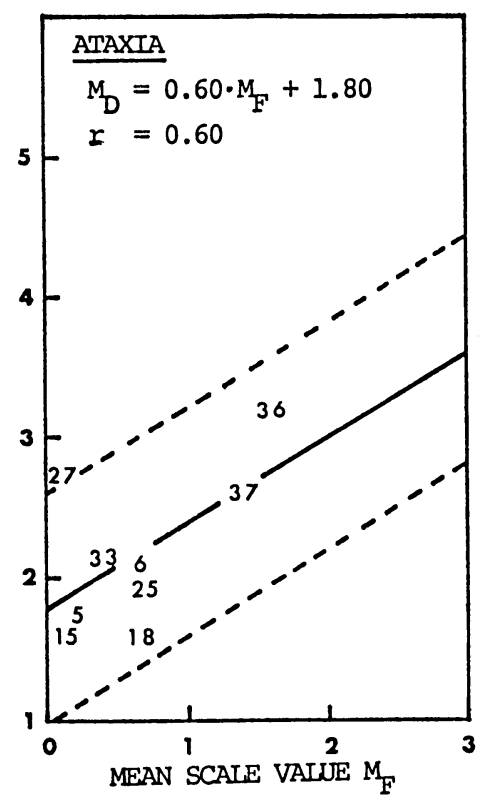

(a) 小脳疾患

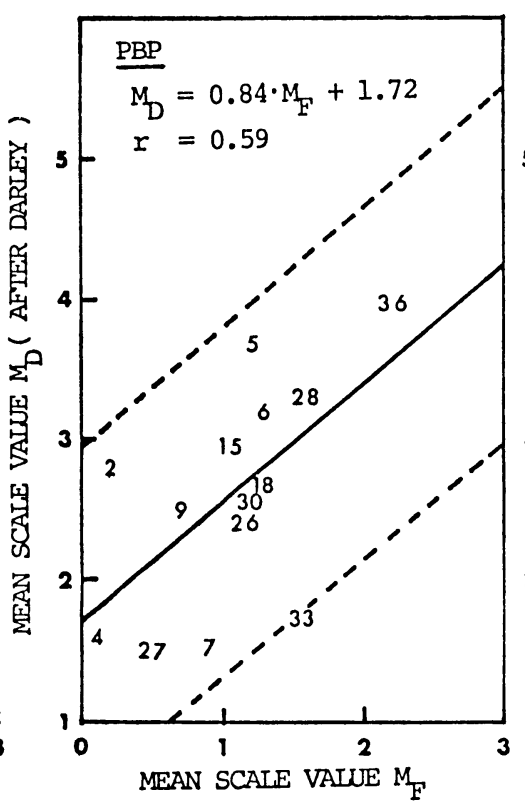

(b) 仮性球麻瘏

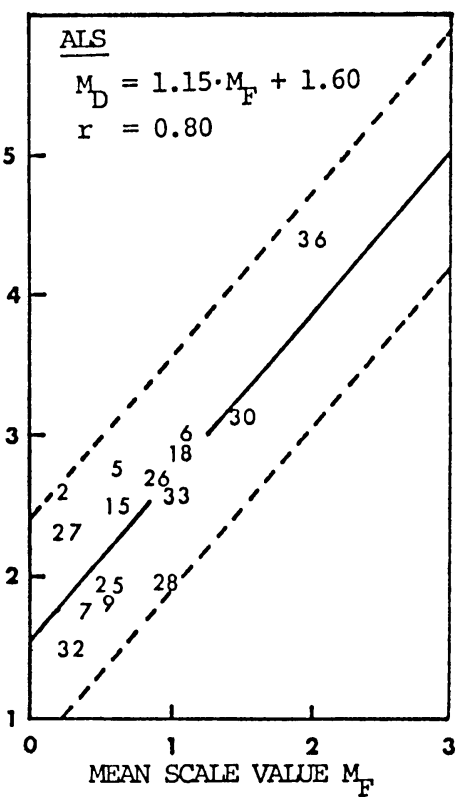

(c) A L S

図 3 今回の結果と Darley らの結果との比較 
て，両者を比較したものである. 図中の番号は今回の評 洒項目，縦軸はこれと対応する Darley らの高得点項目 の MSV (Darley らは 7段階評価であり１が正常を 表す)，横軸は今回の M S V である。図中の実線は回 州直線であり，そこから予測の標準誤差 $\mathrm{S}_{\mathrm{DF}}$ の 2 倍だ け離れたところに点線を引いてある。ここで，点線の外 側にある項目を, 今回の結果と Darley らの結果で著し い違いのあった項目とみなすことにする。このように緩 い基準を用いた理由は，上で述べたように，評洒方法に 差があること，拉よび高得点項目のみの此較しか行えな いためである. 四から明らかなように，両者の結果は， 比較的相関が高く，ある程度類似した結果が得られたと いえよう。しかし，一方，いくつかの相違点も認められ た. 小脳疾患群では, 項目 27 (過度で平板な強勢) でや や違いが見られ，Darley らの方が得点は高くなってい た。この差異の理由の一つとしては, 英 (米) 語と日本 語の言語の違いが挙げられよう. 英 (米) 語の韻律的特 徵, 特に話しことばの強勢に関連する項目についての評 価は, 日本語に拈けるよりも敛密であると思われるの で，そのために二つの結果に差を生じたものと推測され る. また, 仮性球麻疸群では, 項目33（母音のくずれ） で今回の得点の方がやや高かったが, その差の原因は明 らかではなく, 今後の検討が必要である.なお A L S 群
では，両者の結果に大洼がなかった。

次に, 今回の結果を広瀬) の結果についても比較し た. 各群について, 両者に共通する評価項目に関して, 上と同様の方法で表したものが図 4 である。図から明ら かなように, 小脳疾患では, 項目19（速くなったり遅く なったり)を除いて, 両者はほとんど一致している. 項 目19に見られた得点の差は, 今回の評価項目に「音節の 長さの不規則なくずれ」（項目23）といら項目が付加さ れて扣り, より小さな単位での速度の変動を独立に評価 できるようになったためと考劣ることができよう。すな わち, 今回の評価項目のらち, 項目19と23を合わせたも のが，広瀬の研究では「速くなったり遅くなったり」 （項目19に相当）と表現されていたため，この項目の評 洒点が高くなったと解䣋される. 他の 2 群についても, それぞれ 2 項目ずつわずかに違いが見られた。 その一因 としては, 広瀬の場合は, 小脳疾患, 仮性球麻疩, A L $\mathrm{S}$ の症例がとれぞれ $10 ， 8 ， 5$ 例と，いずれも今回に比 ベ少なかったことが挙げられよう。

以上, 聴覚印象に基づく方法によって, 各群の話しこ とばの特徵が明らかとなった。ここで抽出された特徵 が，音響的レベルでどのように反映されるか，または， 神経学的レベルの障害の機構とどのような関係があるか については, 今後の検楌が必要であろう。

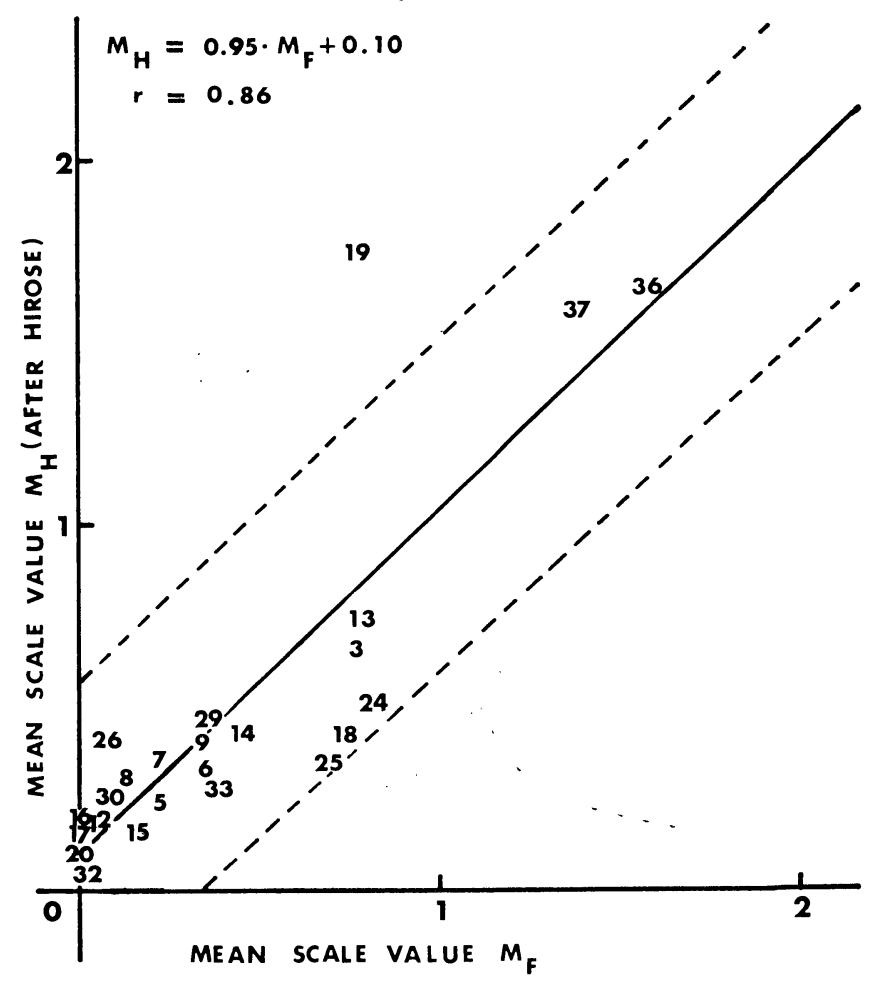

(a) 小脳疾患 


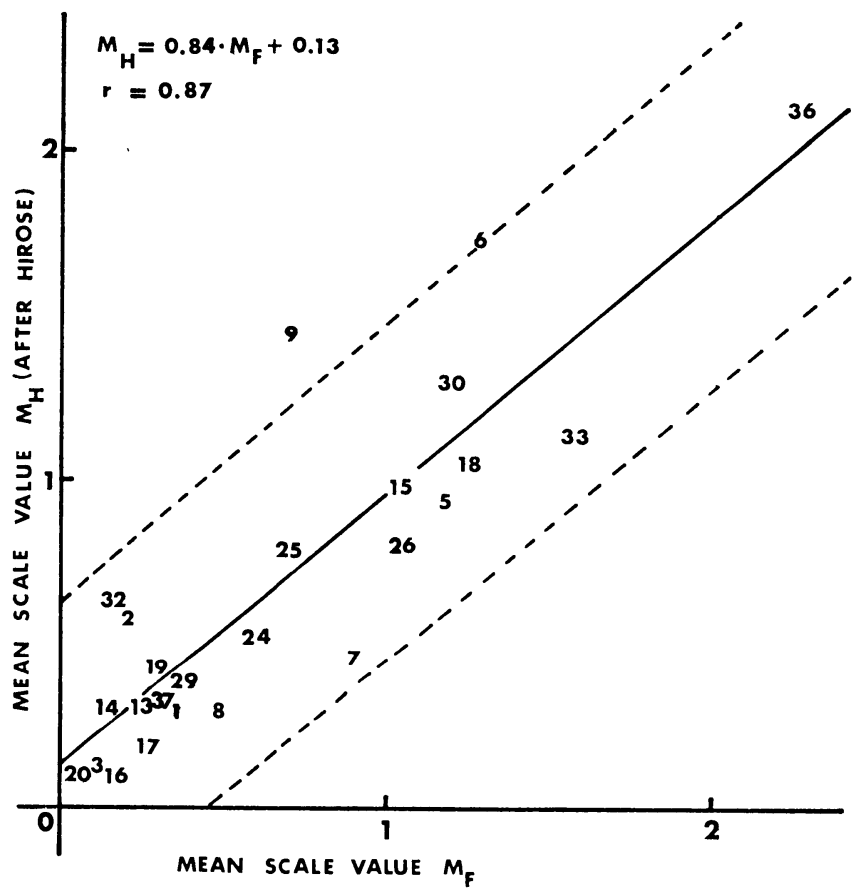

（b）仮性球麻痺

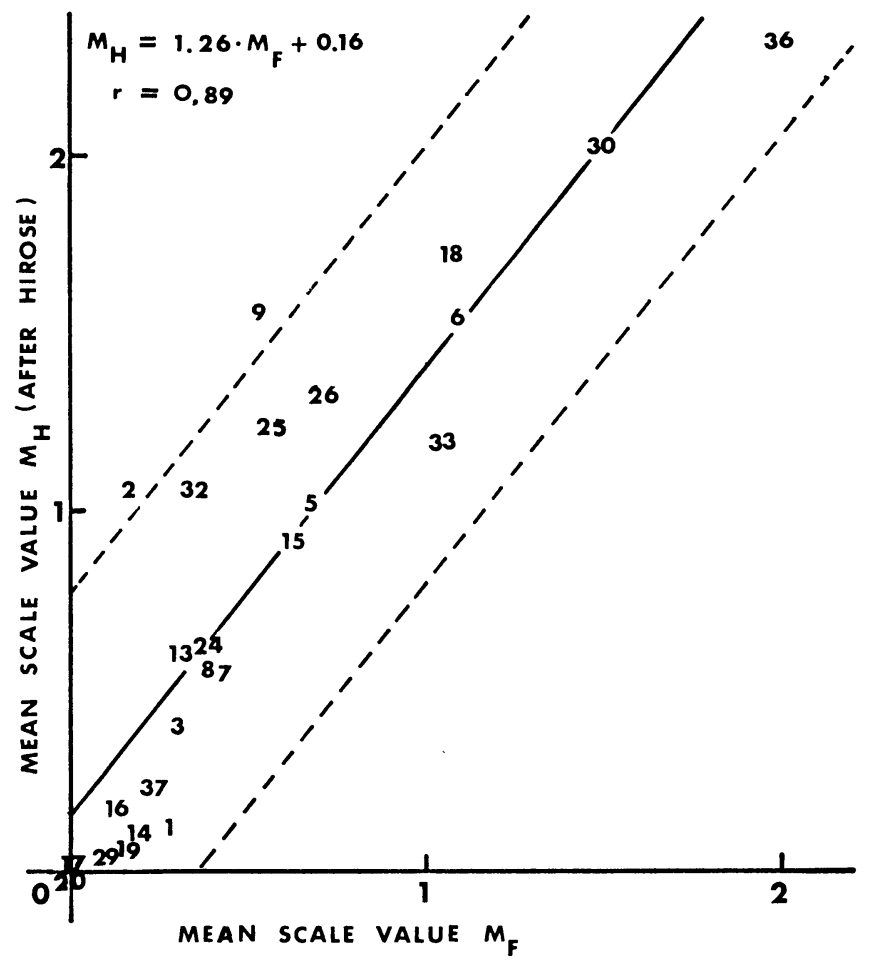

(c) A L S

図 4 今回の結果と広瀬の結果との比較 
また，聴覚印象によって話しことばの特徵を抽出する 方法は, 群全体としての傾向を把握する上で有効な方法 であることがわかった。しかし，そのなかの個々の症例 を比較してみると, 各項目の得点の分布にはバラつきが 認められる.打の括の得点は個々の症例の重症度と関連 があると思われるので, 重症度の変化が各評価項目にど のような影響を与えるかなどについて, 時間的経過を追 って倹討することも今後の課題である.

最後に, 本研究の臨床面における意義について触れた い. 従来用いられていた方法では, 構音器官の形態や機 能が比較的詳細に検查されているのに比べて, 話しこと ばについては，記述的な段階にとどまっていた。われわ れの用いた方法では, 話しことばの特徵を記述するにと どまらず，それを分析的にとら充，乙かも段階的な評価 を行らことが可能である.したがって, 評価項目, 評㑋 方法にはさらに検討すべき点があるものの, 基本的には われわれの用いた方法により, 麻瘦性構音障害患者の話 しことばを評価することは有効であろう。ただし，この 際, 評価者が, 個々の評価項目の表している内容を理解 し，かつ採点法に習熟している必要があることはいうま でもない。

今後は, 今回報告した 3 聅患群に加えて, 麻㽻性構音 障害の主要疾患群の一つであるパーキンソン病について も特徵抽出を行う予定である.

\section{4. まとめ}

中枢神経障害による各種の麻㾖性構音障害患者の話し ことばの特徵を聴覚印象に基づいて分析した。

小脳疾患 20 名, 仮性球麻痺 20 名拉よびA L S 30名の文 と音節の繰り返しに関する発話サンプルを, 39の評価項 目について段階評価を行った。評価者は, 耳鼻咽喉科医 師 1 名, 言語治療士 7 名の合計 8 名であった。

各疾患群の平均得点について検討した結果, 「子音の くずれ」,「子音の省略」,「遅すぎる」および「音の引き 伸し」の 4 つの項目は, どの疾患群でも共通に異常度が 高かった。これはわれわれが臨床上持っている印象, す なわち，いずれの疾患の話しことばにも，構音の正確さ の障害, 拈よび発話速度の障害があることと一致した。 一方，それぞれの疾患に共通でない，むしろ特異的とも いえる高得点項目は, 小脳垁患では, 発声発語に際して の変動性または不規則性に関する項目，仮性球麻盘やA
L S では, 構音の正確さ, 声質, 単調さに関する項目で あった。

さらに, 仮性球麻瘒と A L S の評価項目間の相関は著 しく高く, 両疾患群がきわめて類似していることが示さ れた。強いて両群の違いを挙げれば，AＬＳでは「開鼻 性」の異常度が高かかったことである。これは，AＬＳ では, 口蓋帆の筋萎縮などの下位運動ニューロンの障害 があることを示すものと思われた。また，小脳疾患は， 他の 2 群との相関が低く, 話しことばの特徵が他の 2 群 とは異なることが示された。

それぞれの聅患の話しことばの特徵は，四肢などに発 現する運動障害と対応するものと推論された。

今回の結果は，Darley ら抢よび広瀬の結果と多くの 点で一致していた.

稿を終えるにあたり，評㑛にご協力いただいた 北里大学病院 の小川展子, 熊井和子, 中央鉄道病院の白石幸枝の諸氏，デー 夕の分析にご協力いただいた自治医科大学病院の樋口真理子氏, 資料の收集にこ協力いただいた帝京大学病院の松本多恵氏，な らびに有益な助言をいただいた東京都老人総合研究所言語聴覚 研究室の笹沼澄子室長哚く感謝する。

本研究の要旨は，第20回执よび第21回日本音声言語医学会総 会 (1975年9月抢よび1976年11月) に执いて発表した。

\section{文献}

1) Darley, F. L., Aronson, A. E. and Brown, J. R.: Differential diagnostic patterns of dysarthria. J. Speech Hear. R., $12:$ 246-269, 1969.

2 ) Darley, F. L., Aronson, A. E. and Brown, J. R. : Clusters of deviant speech dimensions in the $\mathrm{dy}$ sarthrias. J. Speech Hear. R., 12:462-496, 1969.

3 ) Darley, F. L., Aronson, A. E. and Brown, J. R. : Motor Speech Disorders. W. B. Saunders Company, Philadelphia, 1975.

4 ）広瀬 㹈: ことばの障害一一症候論, 診断学の立場 から一. 切替一郎編; 中枢神経障害へのアプロー チ, 金原出版, 1973. pp.214-232.

5 ) 小林範子, 福迫陽子, 安藤真理子, 広瀬 肇: 小脑 疾患患者の話しことばの特徵. 聴覚言語障害, 5 : 63-68, 1976. 